\title{
A SUMMARY EVALUATION OF THE TAFT-HARTLEY ACT
}

\author{
CLYDE W. SUMMERS
}

$\mathrm{A}^{\mathrm{n}}$

FTER ten years of Taft-Hartley, it is time to look back; but looking back can be a deadly indulgence. If we seek to justify our past, or if we long to return, we can like Lot's wife be turned to a pillar of salt standing helpless on the desert. Our backward glance is deadening unless we look through the past to see guidelines for the future. Our appraisal must be more than a judgment of whether the Act has succeeded or failed -it must give us wisdom to go forward. It should give us greater insight as to future steps in the development of labor law.

The Act has remained substantially unchanged for ten years. This does not prove its validity, but may only demonstrate the obstacles to legislating in the field of labor-management relations. Certain defects in the statute and the need for clarifying or corrective legislation have been painfully obvious. The thicket of words in Section 8(d) which purports to define the duty to bargain has

In presenting the only over-all appraisal of the Taft-Hartley Act in this symposium, the author of this article evaluates the record of the Act in terms of the aims of its framers in 1947. He concludes that the Act has had far less impact on labor relations than had been desired by its proponents or feared by its critics, and he suggests some explanations for this development.

Clyde W. Summers is professor of law at Yale University.-EDIToR baffled the Board and the courts for ten years; ${ }^{1}$ the latent vacuity of Section 301 , which allows suits for breach of contracts, was laid bare by the Supreme Court in the Westinghouse case; ${ }^{2}$ the disruptive impact of the closed shop provisions on the building trades has been uniformly recognized; the wishful optimism of the cession clause in Section 10(a) produced a foreboding fear of a "no-man's land" between federal and state power, and now the Supreme Court's barbed wire entanglements have made that fear a reality. $^{3}$ In spite of all these patent defects, political pressures have brought no corrective action but only legislative paralysis. In this area the interests are so strong and so deeply held that the gradual evolving of legislation is impossible. We do not move by small steps but rather by sporadic leaps. The last ten years have emphasized the need to legislate with the greatest care and foresight, for even bad provisions may live long.

It is not the purpose of this article to make a personal judgment of the worth of the statute, for that would reveal only the personal scale of values against which

\footnotetext{
${ }^{1}$ For a brief sketch of some of the conflicting views this section has generated, see Justice Frankfurter's concurring opinion in NLRB v. Lion Oil Co., 352 U.S. 282 (1957).

${ }^{2}$ Westinghouse Salaried Employees Ass'n. v. Westinghouse Electric Corp., 348 U.S. 437 (1955).

${ }^{3}$ Guss v. Utah State Labor Relations Board, 353 U.S. 1 (1957).
} 
the statute is measured. The purpose here is rather to appraise the statute according to the values sought to be achieved by those who drafted and enacted it. We may thereby gain greater insight as to the implications of those objectives and the effectiveness of various legal means in achieving them.

In the drafting of the Act at least four separate goals were explicitly stated. The first was, in the words of the Senate Committee Report, "to equalize existing laws" 4 in order to establish "the equality of bargaining power necessary to maintain industrial peace."5 The second goal was, in the words of the preamble, "to protect the rights of individual employees in their relations with labor organizations." 6 The third was to protect "neutrals"-described by Senator Taft as "third persons who are wholly unconcerned in the disagreement." 7 The fourth goal was to obtain stability in labor relations by making collective agreements binding with effective legal sanctions.

These were the stated objectives; the question is, to what extent has the statute succeeded in achieving these objectives, and to what extent has it failed? If we can understand more clearly why it has succeeded or failed, we may know better how to legislate in the future.

\section{UNION-MANAGEMENT EQUALITY}

The first stated goal, achieving equality between unions and management, was blurred by confusing legal equality and economic equality. The sense of injustice rooted in the "one-sidedness" of the Wagner Act led to a demand that both parties

\footnotetext{
${ }^{4}$ Report of the Senate Committee on Labor and Public Welfare, S. Rep. No. 105, 80th Cong., 1st Sess. (1947), p. 2.

${ }^{5}$ Ibid.

${ }^{6}$ Labor Management Relations Act of 1947, Sec. 1.

${ }^{7}$ Cong. Rec., 80th Cong. 1st Sess., Vol. 93 Part 3 April 29, 1947, p. 4323.
}

should be equally subject to legal restraints. To some extent the statute accomplished this form of equality. The unfair labor practice of employer restraint and coercion under Section 8(a)(1) was partially matched by a similar restriction on unions in Section 8(b)(1). The employer's duty to bargain was imposed in equal terms on the union. The union and the employer were made subject to the same rules of free speech.

Although these forms of equality provide an aesthetically appealing symmetry, they may ignore vital differences. There is danger in following the old saw that "what is sauce for the goose is sauce for the gander," lest we blindly assume there is no difference between the two-which may come as quite a surprise to both the goose and the gander! The Board's captive-audience rule, giving unions and management equal freedom to have captive audiences, is a kind of spurious equality that assumes that both the goose and the gander can lay eggs. The formally equalizing words of Section $8(b)(1)$ have cast a cloud over the traditional union weapon of organizational picketing which has no equivalent in employer practices. The attempt of Section 8(d) to define simultaneously the duty of the union and the employer to bargain has contributed to the welter of complications in interpreting that clause. Perhaps from these experiences we can learn that matching statutory words will not establish legal equality between such diverse entities as unions and management- that there is a difference between the goose and the gander.

Beyond the goal of legal equality was the more significant desire to equalize bargaining power. This reflects a deeply felt need that collective bargaining works best when the economic strength of the employer is matched by the economic strength of the union. There were claims 
that "some of the practices under the Wagner Act tend to destroy the balance of power in collective bargaining." 8 This claim, however, overlooks at least two pre-1947 rules which were based on the premise of equalizing bargaining strength. The Board's rule that economic strikers who were permanently replaced during the strike were not entitled to reinstatement at the end of the strike was based explicitly on the grounds that this equalized the employer's ability to meet the strike situation. Also, in determining the appropriate unit, the Board customarily considered the effect of the size or nature of the unit on the parties' relative bargaining strength and frequently established multiple-plant units in order that unions would have effective bargaining power. These modest efforts seemed to be insufficient to satisfy the drafters of Taft-Hartley. They declared a desire to do more.

The puzzling fact is that, in spite of the stated objective, a search of the statute discloses few clauses which even point in this direction. On the contrary, by providing for greater fracturing of appropriate units into craft groups, guard groups, and professional employees, the Act destroys some of the flexibility of the Board and may, in certain circumstances at least, tend to destroy the equality of bargaining power which might otherwise be achieved.

There is no evidence that after ten years the bargaining power of unions and employers is more evenly matched than before. Industrial unions in the North may be stronger in proportion to management than they were ten years ago, but in the South unions may be weaker in proportion to management than they were ten years ago. Some unions have become stronger and others have become

\footnotetext{
${ }^{8}$ Supra, note 5 .
}

weaker, but there is no evidence that the changes have been in the direction of achieving a balance with management.

The underlying difficulty is that equality in bargaining power is largely a product of economic forces and not legal rules. The helplessness of a small independent laundry in the face of the Teamsters is an economic fact, and the weakness of the Retail Clerks in dealing with Woolworth or Kresge is not readily remedied by statutory amendments. The Textile Workers Union in the South is too weak to bargain effectively, while the textile manufacturer in the North can scarcely survive. These are economic problems; relative strength is an economic fact. The ability of the law to work changes is limited.

More important, a balance is achieved only by allowing government to put its hand on one or the other side of the scale, but this is one of the very things which we fear most-to have government injecting its hand into the bargaining relationship in order to juggle the scales. The failure of Taft-Hartley to achieve its first objective was the failure of the drafters to recognize the implications of what they sought, and to face them frankly. Oratorical appeals to "equality" substituted for hard wrestling with real problems. The stubborn fact that such equality could be achieved only by a degree of governmental interference which the drafters themselves deplored was glossed over with platitudes and ambiguities. This does not deny the reality of the problem; it only teaches the necessity for a clear understanding of its nature.

\section{PROTECTION OF INDIVIDUAL RIGHTS}

One of the most pervasive purposes of the Act was to protect the rights of the 
individual against his union. ${ }^{9}$ Some of the sponsors termed it a "Bill of Rights for union members." Members were given control over union decisions by requiring votes on union shop clauses and on the employer's last offer in national emergency strikes. Both of these backfired. In union shop elections, the unions won 97 percent of the elections and amassed a favorable vote of 80 percent of all eligible voters. ${ }^{10}$ This provision tended to displace bargaining on the issue, for 10 to 1 votes were impossible for either unions or management to ignore.11 After three years the very ones who sponsored the union shop election urged its abolition because it had obstructed bargaining and encouraged the extension of union security clauses. Worker approval of the union's action was equally overwhelming in the employer last-offer votes. ${ }^{12}$ The tedium of runaway majorities was broken only by the comic relief of the inability of the government, in the American Locomotive case, to find the last offer on which to vote. These votes too have tended to harden bargaining positions at just the stage where pressures for compromise should be the greatest, and the wisdom of eliminating the provision is now generally conceded.

This experience does not prove that

${ }^{9}$ The Conference Report spoke of giving "further protection to the individual worker against arbitrary action by the union" by the union shop clause of $8(a)(3)$. H.R. Rep. No. 510, 80th Cong. 1st. Sess. p. 41. Amendments to 9(b) were justified on the basis of "recognizing and protecting the rights and interests of individuals and minorities." Id. at p. 47.

${ }^{10}$ Thirteenth NLRB Ann. Rep. for the fiscal year ending June 30, 1948, p. 2; 14 Ann. Rep., p. 8; 15 Ann. Rep., p. 12.

${ }^{11}$ John A. Hogan, "The Meaning of the Union Shop Elections," Industrial and Labor Relations Review, Vol. 2, No. 3 (April 1949), p. 319.

${ }^{12}$ Herbert S. Parnes, Union Strike Votes, Current Practice and Proposed Controls, Princeton, 1956, p. 105. workers mass-mindedly agree with their union officers, or that they follow like sheep. It does demonstrate that if workers are required by law to vote on their union's demands, they consider it a public declaration of their choice between their union leaders and the employer. For the worker, that choice is obvious. The vote is not only futile, but tends to solidify the leaders' position and stifle protests within the union.

Another method of protecting the individual was to give him a degree of independence from control by the majority union. The priviso in Section 9(a), giving the individual a right to process his own grievance, was amended to repudiate previous decisions of the Board and to create in the individual an independent right to enforce the collective bargaining agreement on his own behalf. He was given the right to process his grievance "without intervention of the bargaining representative" to insure that his rights under the contract would not be surrendered or compromised. ${ }^{13}$ This provision has proved of little worth. Unions dislike individual grievances for it tends to undermine their authority, and most employers prefer that all grievances be regularized by processing through the union procedure. Also, employers are not anxious to antagonize the union by granting a claim which the union rejects. Encouraged by a questionable ruling of the General Counsel, ${ }^{14}$ unions and employers have negotiated clauses explicitly prohibiting the right of the individual to process his grievance, thereby bargaining away the individual's statutory right.

The experience under this section suggests that employers are not always vigilant protectors of individual rights. The employer seeks trouble-free produc-

\footnotetext{
${ }^{18}$ S. Rep., p. 24.

${ }^{14}$ Admin. Rul. Case No. 317; Case No. 418
} (1952). 
tion, not unnecessary disputes. It further suggests that the protection of individual or minority rights is extremely difficult if these rights conflict with the mutual interests of the employer and the union. Statutory provisions intended to protect these rights must be crystal-clear and specially designed to prevent circumvention.

The individual is also given a degree of independence by the union security clauses of Sections $8(a)(3)$ and $8(b)(2)$. These were explicitly designed "to meet numerous examples of glaring disregard for the rights of minority members of unions"15_exclusion of Negroes, admission only of sons of members, and expulsion of those who opposed the union leadership. Although the clause does give broad protection to job rights, it does not give the individual any right to participate in the affairs of his union. Negroes can still be relegated to subsidiary locals and have their contracts negotiated by all-white locals. Opponents can still be expelled and politically sterilized. Even job protection is not complete, for the union may induce the employer to discharge individuals because they are "left-wingers," or because they don't drive a Studebaker. Union democracy is not encouraged or protected, and the individual is left helpless in the face of union-management cooperation.

These, however, suggest only the loopholes in the law-its gross failure to meet its stated objective. The real failure of the law is that it has not been obeyed. The closed shop and hiring hall are still standard practice in the construction industry and are only thinly disguised in printing, longshore, and maritime. In the building trades the established practice of the unions and employers is to ignore the law, pay any claims filed, and keep

\footnotetext{
${ }^{15}$ S. Rep., p. 7.
}

away from the courts. The very industries in which the abuses were most severe have not changed their ways.

The moral here again is that it is difficult to legislate against union-management cooperation, but the problem runs much deeper. The closed shop, closed union, and hiring hall-an inseparable trilogy-persist because of practical needs of both unions and employers. In industries where employment is short-term, seniority structures are impossible. Those workers who are established in the industry seek priority of job rights by requiring that new entrants wait until established workers are employed. The auto worker, the steel worker, and even the office worker has his seniority clause which gives him job priority. In these industries there is no "free labor market"; a man cannot get a job where he wants it. For the hodcarrier, the bricklayer, or the carpenter, the closed shop trilogy provides his substitute for seniority. The statute attempted to wipe out all this and substituted nothing it its place. This desperate need for job priority cannot thus be wished away with a wand of words. The employers' need is nearly as compelling. In these industries the employer needs a pool of labor on which to draw on short notice; he cannot advertise or even maintain an adequate personnel department. The hiring hall is a practical and proven solution.

The Taft-Hartley Act gave no recognition to these stubborn economic facts. Where there were genuine economic needs of the parties, it attempted to create a vacuum. It blandly assumed that, if the union were prohibited from having a closed shop, the employers would protect the individuals. The signal lesson of the Taft-Hartley Act is that when the union's needs are acute, and when the employer's needs or desires for cooperation are strong, legal measures must be 
carefully constructed to permit the creating of new institutions to meet the genuine needs. If the individual is to be protected, both unions and management need to be told clearly that they cannot interfere with his rights even though it is to their mutual advantage, and stringent measures must be provided to curb their interlocking interests.

\section{PROTECTION OF NEUTRALS}

The third stated objective of TaftHartley was the protection of "neutrals." This was sought through the unfair labor practices defined in Section 8(b)(4) and the equivalent damage actions provided by Section 303. These provisions have had substantial effect in reducing the use of secondary pressures, and their impact is reflected in the number of cases which the Board has handled. Again, one of the most troublesome problems has been union-management cooperation, this time in the form of "hot cargo" clauses. Beyond this, the problems have centered on defining who is "neutral," particularly in cases involving construction projects, truck trailing, and "unfair lists."

These problems are but symptomatic of the more fundamental difficulty in defining neutrals in labor disputes. Collective bargaining depends ultimately, in some situations, on a trial of strength. When the employer and the union cannot agree, other people get hurt-the railroad loses its shipper, the parts-supplier loses his customer, and the customer is denied the product. The economy inevitably transmits the shock to innocent parties, "persons who are wholly unconcerned in the disagreement." This is the price we pay for free collective bargaining; this is a cost which we deem preferable to government intervention. The basic fallacy of this appealingly worded objective of protecting "neutrals" is that it is at war with the inherent character of collective bargaining.

The secondary boycott provisions were constructed on the principle that somehow a little circle could be drawn around the conflict, and that the conflict could then take place solely within the circle. It seems more sensible to face quite openly the fact that outsiders are going to be hurt. Insofar as there is any attempt to quarantine the dispute, the quarantine should not be based on moralistic grounds that innocents will be injured. Instead, the bounds of quarantine should be defined so as to achieve other objectives of the statute, particularly that of equalizing bargaining power.

The Board and the courts, when faced with concrete situations instead of misleading moral abstractions, have attempted to shape the statute to promote bargaining equality. In the Ebasco case, ${ }^{16}$ the court held that when a struck employer moved work to another company, the union could follow the struck goods and picket at the other plant. If this were not permitted, the union would not have equality of bargaining power. In the Royal Typewriter case, ${ }^{17}$ a business machine company which was on strike farmed out its service contracts to independent repair firms. When the union picketed these secondary employers, the Board upheld the right of the union to bring economic pressure against "allies." Otherwise the union's economic force would be lost. When the Teamsters in Buffalo had a dispute with an association of linen supply companies, they struck one of the companies, but allowed the others to operate- a divide and conquer, or "whipsaw" device. The employers countered by all ceasing operation. The

\footnotetext{
${ }^{16}$ Douds v. Metropolitan Federation of Architects, 75 F. Supp. 672 (S.D. N.Y., 1948).

${ }^{17}$ NLRB v. Business Machines Mechanics, 228 Fed. 553 (2d Cir., 1955).
} 
Board's ultimate conclusion, affirmed by the Supreme Court, was that small employers who bargained as a single unit could combine their forces to meet the onslaught of a strong union. ${ }^{18}$ If the union struck one, the rest could present a solid front by closing down in a sympathy lockout. Crocodile tears for the poor employees who did not go out on strike, but who were nevertheless locked out by their employer, avail nothing. They were innocents, in a sense, but they were not immune from loss due to the processes of collective bargaining.

The objective of protecting "neutrals" has strong emotional appeal akin to a moral principle, but to legislate on this basis is to ignore economic realities. Such slogans only divert us from the difficult problems of defining the boundaries of the dispute in such a way as to promote objectives which improve the functioning of our collective bargaining system.

\section{SANCTITY OF CONTRACTS}

The fourth objective of the statute was to provide for sanctity of contracts. Underlying this was a broader objective of providing for stability of labor relations during the contract term. Section $8(d)$ sought to provide stability by requiring that the contract continue in full force and effect for sixty days after notice of termination or until the expiration date, whichever is later. It also explicitly stated that a party was not required to discuss modifications during the contract term. This section was supplemented by Section 301 which provides for suits for breach of contract.

The major weakness of these sections has been their defective draftsmanship. The murky wording of Section 8 (d) has led the Board and the courts to an assortment of interpretations, and only now

\footnotetext{
${ }^{18}$ NLRB v. Truck Drivers Local Union No. 449, 353 U.S. 87 (1957).
}

after ten years do some glimmers of light begin to show through. The source of the confusion was the failure of the drafters to consider the wide variety of fact situations which might arise and to determine how each type of situation should be handled. The Board and the courts had to find the intent of the drafters who had not given enough thought to have an intent. The various wording of Section 301 was likewise a product of failure to think through the legal problems. The Westinghouse case $^{\mathbf{1 9}}$ cast a shadow across the section for two years; the Lincoln Mills decision ${ }^{20}$ removed the shadow but left a host of questions that will plague the courts for years. The most elementary lesson is plain-collective bargaining is a complicated process, and it operates in an intricate complex of legal rules and procedures. The drafting of statutes requires the greatest care and intensive examination for dangerous gaps and booby traps. Perhaps the inherent problem is that the legislative process as it now functions is incapable of meeting the severe demands placed upon it in developing statutes in this area.

The sanctity of contract and stability of relationships has not been furthered by the Supreme Court's interpretation of these sections. Most thought-provoking is the Mastro Plastics Products Company case, ${ }^{21}$ in which the union struck during the contract term because the employer had discharged a man for union activity. Although the union had two legal remedies-a suit for breach of contract and a charge of unfair labor practice-the Court upheld the union's right to strike. Neither the no-strike clause (lacking an explicit prohibition of unfair labor practice strikes) nor the

${ }^{19}$ Supra note 2 .

${ }^{20}$ Textile Workers Union of America, v. Lincoln Mills, 353 U.S. 448 (1957).

${ }^{21}$ Mastro Plastics Corp. v. NLRB, 350 U.S. 270 (1956). 
statutory no-strike provisions of Section 8 (d) barred the union from using selfhelp. In spite of the words and spirit of the statute, recourse to the law of the jungle was still countenanced during the contract term.

Far more effective in defeating this objective of the statute has been the conduct of the parties themselves. Immediately after the passage of the Act, John L. Lewis led the way by negotiating his famous "ready, willing, and able to work" clause. Over 40 percent of the contracts now have clauses which protect the unions from liability under Section $301 .^{22}$ The Lion Oil case ${ }^{23}$ has now opened an escape route for the parties to avoid the strictures of Section $8(d)$ by including a clause allowing for reopening on sixty days' notice. Even where contracts have effective clauses, employers have understandably been reluctant to enforce them with vigor. Again, the process of collective bargaining has significantly limited the impact of the statutory provisions.

\section{CONCLUSION}

It is reasonably clear that none of the objectives of the framers of the Act has been achieved in full measure. Sanctity of contracts has measurably increased, although it is debatable whether this has been due more to the temper of the times than to the impact of the jumbled legal provisions. Individuals have gained a small measure of protection. Equality of bargaining strength, a real and pressing need, has not been achieved, while the false objective of protecting neutrals has been vigorously pursued without any consideration of the possibility that limiting the scope of the conflict might be used constructively to help equalize bargaining power.

\footnotetext{
${ }^{22}$ Bureau of National Affairs, Contract Clause Finder 77:151-155.

${ }^{28}$ NLRB v. Lion Oil Co., 352 U.S. 282 (1957).
}

Running through the whole problem of legislating in the field of union-management relations is a continuous struggle between the demands for government intervention in collective bargaining and the demands for the freedom of the parties to make their own choices. The parties' choices are dictated by economic facts, not political or social values. To impose those values by legislation requires a full recognition of the parties' economic needs and the pressures which motivate them. The legal measures must either meet those needs, divert the pressures, or be forceful enough to compel the parties to bow to the social values sought by the legislation. The drafters of Taft-Hartley failed to reckon with the nature and strength of the economic forces and institutions involved. Employers were entrusted with protecting individual rights, job priority systems in transient industries were ordered to disappear, equality was desired with no critical thought of whether or how it might be achieved, and stability was sought without serious consideration whether it should be optional or compulsory on the parties.

Ten years have made clear that the mutual interests of union and management cannot be easily defeated by legal measures. Individual rights within the collective structure cannot be protected by half measures, because such rights frequently run counter to the desires of both collective parties. It is both a warning and an encouragement that free collective bargaining has a far greater reservoir of strength than we dreamed ten years ago. One might say that the downfall of Taft-Hartley was that its sponsors overestimated the ability of government intervention to control private collective action. They underestimated the strength of laissez-faire. 